\title{
Plagiarism in the construction of scientific papers
}

Marli Teresinha Gimeniz Galvão ${ }^{1}$

In different levels of access to knowledge, from elementary school to higher education, there are concerns regarding the ease of access to information available on the Internet, whose content is copied, often arbitrarily. However, there is a growing concern to ensure that "copies" are used as quotes and with due recognition of the real author. Thus, plagiarism has increased dramatically, especially in the context of scientific research publications, with cases not only in the field of postgraduate programs, but also in scientific activities in general ${ }^{(1)}$.

Plagiarism is when someone takes possession, as if it were his own, of results or conclusions of another author, as well as full texts or a substantial part of other people's texts without taking care of important factors such as authorial merit. Someone who takes possession of ideas or data obtained in the analysis of projects or unpublished manuscripts, to which they had access as a consultant, reviewer, editor or something similar, also commits plagiarism $^{(2)}$.

There are different types of plagiarism. Among these, direct plagiarism, which consists in copying verbatim excerpts of work without indicating they are a quotation and without reference to it; partial plagiarism, also called mosaic plagiarism, resulting from the selection of parts of the text or phrases, collages formed by one or several authors, without mentioning their sources; accidental plagiarism, i.e., the use of ideas, rewritten in a different way, without citing the original reference. There is also the self-plagiarism, which consists of full or partial presentation of different materials, such as texts and results of new research, published by the same author in earlier studies without appropriate references to those studies ${ }^{(2)}$.

Regardless of the form of copying, plagiarism is always a dishonesty and a violation of copyright, and the plagiarist may be liable to civil and criminal actions, because it is a reproduction of essays, results or ideas, which are protected by law, which is public and explicit ${ }^{(3)}$.

The scientific community has discussed ethics in the creation and publication of public texts, such as articles, theses, dissertations, monographs, book chapters, abstracts, among others distributed without identifying authorship and without reference sources.

In Brazil, the National Council for Scientific and Technological Development (CNPq) proposed a set of guidelines to promote ethics in the publication of scientific research and established parameters to investigate possible misconduct ${ }^{(2)}$. Among the guidelines indicated by CNPq, the following were highlighted: "Authors should always give credit to all sources that directly underlie their work; when summarizing someone else's text, authors should seek to reproduce the exact meaning of ideas or facts presented by the original author, who should be cited; when submitting a manuscript for publication containing information, conclusions or data that have been disseminated significantly, authors should indicate clearly to the editors and readers the existence of prior disclosure of information; to avoid any characterization of self-plagiarism, the use of texts and previous work of the authors themselves should be marked with appropriate references and citations"2.

Whatever the type of plagiarism, it might mean a total loss of credit and reliability of the plagiarist towards his colleagues.

\footnotetext{
${ }^{1}$ Universidade Federal do Ceará. Fortaleza, CE, Brazil.

${ }^{2}$ Available from: http://memoria.cnpq.br/normas/lei_po_085_11.htm. Cited 2014 Apr 20.

Corresponding author: Marli Teresinha Gimeniz Galvão

Rua Alexandre Baraúna, 1115 - Rodolfo Teófilo. Fortaleza, CE, Brazil. CEP: 60430-160. E-mail: marliglavão@gmail.com
} 
Currently, plagiarism happens due to the ease and technological advances of communication and because of the plethora of information provided by virtual libraries, providing access to different productions. This fact has enabled users to take advantage of materials for intellectual enrichment. However, at the same time, it allows them to use the information incorrectly or with ulterior motives, without giving due credit to the real authors $^{(4)}$. Inadvertently, plagiarists employ the use of the "copy-paste" resource to formulate texts.

Given this behavior, the total or partial copy can be detected through various resources. Initially, an attentive reading of a document by professors/supervisors may lead to suspicion of the authorship of a text because of the way it was described, particularly in the structure of writing and use of uncommon words or the author's vocabulary. Broadly, one stimulates plagiarism scan, using search engines, anti-plagiarism programs for detecting copies of excerpts or entire pieces of work. The choice of using a program shows a rate of similarities, highlighting key words, phrases, sentences and paragraphs.

Results of a study designed to evaluate the term plagiarism indicated about 8,000 articles in English ${ }^{(5)}$. As these results indicate, although a study passes by careful analysis before being published, the opinion givers, during previous analyzes fail to detect any improprieties, including the copying of other studies. Thus, the detection of plagiarism is one of the most difficult tasks for the editorial board of a magazine. One of the roles of editors and reviewers is the specialized search in different databases in order to identify if the text brought to publication has already been disclosed by those authors or by other authors.

One of the principles of the Rev Rene is to prevent the approval of content characterized as plagiarism. As a precautionary measure, it is adopted upon the article's submission a letter to be signed by all authors stating the originality of the article, so containing no plagiarism. Also, during the review of the manuscript made by colleagues, one seeks to minimize the possibility of dissemination of content considered as plagiarism.

\section{References}

1. Sabatini M. Do plágio à publicidade disfarçada: brechas da fraude e do antiético na comunicação científica. Com Ciência [on-line]. 2013 [citado 2014 jun 2]; 147. Disponível em: http://www.comciencia.br/comciencia/ handler.php?section=8\&edicao=87\&id=1071.

2. Conselho Nacional de Desenvolvimento Científico e Tecnológico (CNPq). Ética e integridade na prática científica. Relatório da Comissão de Integridade de Pesquisa do CNPq [Internet]. [citado 2014 abr 20]. Disponível em: http://memoria.cnpq.br/normas/lei_po_085_11.htm

3. Instituto de Arte e Comunicação Social. Nem tudo que parece é: entenda o que é plágio [Internet]. 2010 [citado 2014 mai 13]. Disponível em: http://www.noticias.uff.br/arquivos/cartilha-sobre-plagio-academico.pdf

4. Moraes R. 0 plágio na pesquisa acadêmica: a proliferação da desonestidade intelectual. Rev Diál Possíveis. 2004; 1:92-109.

5. Chamon W. Plágio e má conduta na pesquisa: onde estamos e o que podemos fazer. Arq Bras Oftalmol. 2013; 76(6):5-6. 